\title{
DINAMIKA PENDIDIKAN KEWARGANEGARAAN DI INDONESIA DARI REZIM KE REZIM
}

\author{
Oleh: Sunarso \\ (Jurusan PKn dan Hukum FISE / MKU - UNY)
}

\begin{abstract}
Abstrak
Kepentingan politik penguasa terhadap Pendidikan Kewarganegaraan (PKn) di Indonesia dapat dirunut dalam sejarah perkembangan mata pelajaran ini, sejak munculnya dalam sistem pendidikan nasional pada era Orde Lama hingga Orde Reformasi. Mata pelajaran PKn ini muncul pertama kali tahun 1957.

Pendidikan Kewarganegaraan mempunyai misi yang khas. Mata pelajaran ini menonjol dengan misinya untuk mewujudkan sikap toleransi, tenggang rasa, memelihara persatuan dan kesatuan, tidak memaksakan pendapat, dan lain-lain, yang dirasionalkan demi terciptanya stabilitas nasional sebagai prasyarat bagi kelangsungan pembangunan.

Di balik semua itu Pendidikan Kewarganegaraan sesungguhnya telah berfungsi sebagai alat penguasa untuk melanggengkan kekuasaan. Sosok Pendidikan Kewarganegaraan (Civic atau Citizenship Education) yang demikian memang sering muncul di sejumlah negara, khususnya negara-negara berkembang termasuk Indonesia seperti yang dikemukakan oleh Cogan (1998).
\end{abstract}

\section{Pendahuluan}

Jatuhnya Soeharto dari kekuasaan pada Mei 1998, berikut dengan krisis moneter, ekonomi, dan politik, telah mendorong reformasi bukan hanya dalam bidang politik dan ekonomi, tetapi juga dalam bidang pendidikan. Pendidikan nasional menurut banyak kalangan bukan hanya belum berhasil meningkatkan kecerdasan dan keterampilan anak didik, melainkan gagal dalam membentuk karakter dan kepribadian (nation and character building). Padahal pembentukan karakter dan kepribadian ini sangat penting, bahkan sangat mendesak, karena masih berkelanjutannya berbagai krisis yang melanda bangsa dan negara Indonesia hingga saat ini (Azyumardi Azra, 2006: vi)

Paradigma pendidikan yang dianut pada masa Orde Baru adalah "pendidikan untuk pembangunan", sehingga pendidikan telah diposisikan sedemikian rupa sebagai instrumen pembangunan. 
Pembangunan Manusia Indonesia Seutuhnya yang menjadi jargon Orde Baru dalam kebijakan dan operasionalnya ternyata lebih banyak berpihak dan berorientasi pada pertumbuhan ekonomi. Pengalaman pada masa Orde Baru itu telah memberikan pelajaran "berharga" tentang betapa rapuhnya suatu pembangunan yang hanya menekankan pada aspek phisik-materiil dan kepentingan-kepentingan ekonomi belaka (Muchson, 2004).

Pendidikan Kewarganegaraan mempunyai misi yang lebih khas. Mata pelajaran (mata kuliah) ini menonjol dengan misinya untuk mewujudkan sikap toleransi, tenggang rasa, memelihara persatuan dan kesatuan, tidak memaksakan pendapat dan lain-lain, yang dirasionalkan demi terciptanya stabilitas nasional sebagai prasyarat bagi kelangsungan pembangunan. Di balik semua itu Pendidikan Kewarganegaraan sesungguhnya telah berfungsi sebagai alat penguasa untuk melanggengkan kekuasaan. Sosok Pendidikan Kewarganegaraan (Civic atau Citizenship Education) yang demikian memang sering muncul di sejumlah negara, khususnya negara-negara berkembang, sesuai dengan laporan penelitian Cogan (1998) yang dikutip oleh Ace Suryadi dan Somantri (2000:1) yang mengatakan:

"Citizenship education has often reflected the interest of those in power in particular society and thus has been a matter of indoctrination and the establishment of ideological hegemony rather than of education".

Kepentingan politik penguasa terhadap Pendidikan Kewarganegaraan di Indonesia dapat dirunut dalam sejarah perkembangan mata pelajaran (mata kuliah) ini, sejak munculnya dalam sistem pendidikan nasional. Mata pelajaran (mata kuliah) ini muncul pertama kali tahun 1957 dengan nama "Kewarganegaraan", yang isinya sebatas tentang hak dan kewajiban warga negara, serta cara-cara memperoleh dan kehilangan status kewarganegaraan. Sebagai tindak lanjut dari Dekrit Presiden 5 Juli 1959, Menteri PP dan K mengeluarkan Surat Keputusan No. 122274/S tanggal 10 Desember 1959 tentang pembentukan panitia penyusunan buku pedoman mengenai kewajiban-kewajiban dan hak-hak warga negara Indonesia dan hal-hal yang menginsyafkan warga negara tentang sebab-sebab sejarah dan tujuan Revolusi Indonesia. Sejak munculnya Orde Baru pada tahun 1966, isi mata pelajaran Civics versi Orde Lama hampir seluruhnya dibuang, karena dianggap sudah tidak sesuai lagi dengan tuntutan yang sedang berkembang. Pada era reformasi sekarang ini Pendidikan Kewarganegaraan juga sedang dalam proses reformasi ke arah Pendidikan Kewarganegaraan dengan paradigma baru (New 
Indonesian Civic Education). Reformasi itu mulai dari aspek yang mendasar, yaitu reorientasi visi dan misi, revitalisasi fungsi atau peranan, hingga restrukturisasi isi kurikulum dan materi pembelajaran.

\section{Tinjauan Umum Tentang Pendidikan Kewarganegaraan}

Secara klasik sering dikemukakan bahwa tujuan Pendidikan Kewarganegaraan di Indonesia adalah untuk membentuk warga negara yang baik (a good citizen). Akan tetapi pengertian warga negara yang baik itu pada masa-masa yang lalu lebih diartikan sesuai dengan tafsir penguasa. Pada masa Orde Lama, warga negara yang baik adalah warga negara yang berjiwa "revolusioner", anti imperialisme, kolonialisme, dan neokolonialisme. Pada masa Orde Baru, warga negara yang baik adalah warga negara yang Pancasilais, manusia pembangunan, dan sebagainya. Sejalan dengan visi Pendidikan Kewarganegaraan era Reformasi, misi mata pelajaran ini adalah meningkatkan kompetensi siswa agar mampu menjadi warga negara yang berperan serta secara aktif dalam sistem pemerintahan negara yang demokratis. Sehubungan dengan itu, Ace Suryadi dan Somardi (2000: 5) mengemukakan bahwa Pendidikan Kewarganegaraan memfokuskan pada tiga komponen pengembangan, yaitu (1) civic knowledge, (2) civic skill, dan (3) civic disposition. Inilah pengertian warga negara yang baik, yang diharapkan oleh Pendidikan Kewarganegaraan di Era Reformasi.

Pendidikan Kewarganegaraan di Era Reformasi dituntut merevitalisasi diri agar mampu melaksanakan misi sesuai dengan visinya itu. Hingga saat ini mata pelajaran tersebut seakan tidak memiliki vitalitas, tidak berdaya, dan tidak dapat berfungsi secara baik dalam meningkatkan kompetensi kewarganegaraan.

Dalam penataannya di dalam struktur kurikulum, Belinda Charles dalam Print (1999: 133-135), merekomendasikan, isi Pendidikan Kewarganegaraan dapat ditata dalam tiga model, yaitu formal curriculum, informal curriculum, dan hidden curriculum. Dengan model formal curriculum, implementasi pembelajarannya dapat menembus berbagai mata pelajaran (cross-curriculum). Model informal curriculum dapat diimplementasikan dalam kegiatankegiatan ekstra kurikuler, seperti kepanduan, klub-klub remaja, PMR, kegiatan rekreasi, dan olah raga. Model ini justru efektif dalam pembentukan karakter remaja. Model hidden curriculum, seperti misalnya etika, dapat dikembangkan dalam tingkah laku sehari-hari. 


\section{Pendidikan Kewarganegaraan sebagai Pendidikan Karakter}

Azyumardi mengklasifikasi penyebab krisis mentalitas, moral, dan karakter mahasiswa di perguruan tinggi yang juga menjadi bagian dari pendidikan nasional. Ada tujuh masalah pokok yang turut menjadi akar krisis mentalitas dan moral di lingkungan perguruan tinggi, antara lain: arah pendidikan telah kehilangan objektivitasnya; proses pendewasaan diri tidak berlangsung; proses pendidikan di sekolah dan perguruan tinggi sangat membelenggu siswa dan mahasiswa, dan bahkan juga guru dan dosen; beban kurikulum yang demikian berat, lebih parah lagi, hampir sepenuhnya diorientasikan pada pengembangan ranah kognitif belaka; beberapa mata pelajaran dan matakuliah, termasuk juga pendidikan agama dan pendidikan kewarganegaraan, disampaikan dalam bentuk verbalisme, yang juga disertai dengan rote-memorizing, pada saat yang sama siswa dan mahasiswa dihadapkan kepada nilai-nilai yang sering bertentangan; siswa dan mahasiswa juga mengalami kesulitan dalam mencari contoh teladan yang baik di lingkungannya (Azyumardi Azra, 2006: xi).

Ketujuh permasalahan tersebut harus dicarikan solusinya. Solusi tidak bisa dilakukan secara adhoc dan parsial. Bahkan dapat dikatakan, pemecahan masalah-masalah besar itu meniscayakan reformasi itu sendiri secara keseluruhan, karena masalah-masalah tersebut saling berkaitan.

Persoalan lain yang dihadapi bangsa ini adalah tentang pembentukan masyarakat madani yang sering disebut civil society, terwujudnya masyarakat demokratis, pelaksanaan otonomi daerah, dan terrealisasinya pemerintahan yang bersih melalui jalur pendidikan nasional. Harus diakui upaya untuk mengaktualisasikan demokrasi dan civil society di Indonesia melalui jalur pendidikan kelihatannya masih harus menempuh jalan panjang, terjal, dan berliku-liku. Oleh karena itu, Pendidikan Kewarganegaraan di sekolah dan di perguruan tinggi harus melakukan reorientasi, rekonstruksi kritis, restrukturisasi, dan reposisi, serta berusaha untuk menerapkan paradigma baru. Upaya-upaya itu harus bertujuan akhir pembentukan masyarakat Indonesia yang demokratis, bersih, bermoral, dan berakhlak; dan berpegang teguh pada nilai-nilai civility (keadaban). Sekolah harus memenuhi tiga aspek, yaitu pengetahuan, skill, dan membentuk karakter. Ketiga komponen pokok tersebut, yaitu civic knowledge, civic skills, dan civic dispositions (Margaret S. Bronson, dkk., 1999: 8-25). 
Pengetahuan kewarganegaraan (civic knowledge) merupakan materi substansi yang harus diketahui oleh warga negara. Pada prinsipnya pengetahuan yang harus diketahui oleh warga negara berkaitan dengan hak dan kewajiban sebagai warga negara, pengetahuan tentang struktur dan sistem poitik dan pemerintahan, nilai-nilai universal dalam masyarakat demokratis, cara-cara kerjasama untuk mewujudkan kemajuan bersama, serta hidup berdampingan secara damai dalam masyarakat internasional. Keteramtpilan kewarganegaraan (civic skills), merupakan keterampilan yang dikembangkan dari pengetahuan kewarganegaraan, agar pengetahuan yang diperoleh menjadi sesuatu yang bermakna. Civic skills mencakup intellectual skills (keterampilan intelektual) dan participation skills (keterampilan partisipasi). Adapun karakter kewarganegaraan (civic dispositions) merupakan sifat-sifat yang harus dimiliki setiap warga negara untuk mendukung efektivitas partisipasi politik, berfungsinya sistem politik yang sehat, berkembangnya martabat dan harga diri dan kepentingan umum.

Civic Education (Pendidikan Kewarganegaraan) memfokuskan pada demokrasi politik atau demokrasi sebagai sebuah sistem politik. Civic Education sebagai bagian dari sosialisasi politik berfungsi sebagai pemelihara dan pengembang sistem politik yang ideal yaitu demokrasi. Dalam demokrasi konstitusional, civic education yang efektif adalah suatu keharusan. Kemampuan untuk berpartisipasi dalam masyarakat demokratis, berfikir secara kritis, dan bertindak secara sadar dalam dunia yang plural, memerlukan empati yang memungkinkan kita mendengar, dan mengakomodasi pihak lain, semuanya itu memerlukan kemampuan yang memadai.

\section{Pendidikan Kewarganegaraan Pada Era Orde Lama}

Perjalanan sejarah Bangsa Indonesia menunjukkan bahwa pendidikan formal dijadikan sarana untuk mempersiapkan warganegara yang sesuai dengan cita-cita nasional. Upaya itu nampak dari lahirnya berbagai nama untuk Pendidikan Kewarganegaraan (PKn) yang sering berganti-ganti sejalan dengan perkembangan dan pasang surut perjalanan politik bangsa Indonesia. Hal itu ditunjukkan dengan lahirnya berbagai kebijakan di bidang pendidikan khususnya tentang PKn sebagai tindak lanjut dari Dekrit Presiden 1959 untuk kembali ke UUD 1945, di antaranya dengan instruksi pembaharuan buku-buku di perguruan tinggi. 
Pemerintah, dalam hal ini Departemen P dan K, mengeluarkan surat keputusan No. 122274/S, tanggal 10 Desember 1959, membentuk panitia yang terdiri dari 7 orang. Tugas panitia tersebut membuat buku pedoman mengenai kewajiban-kewajiban dan hak-hak warganegara Indonesia disertai hal-hal yang akan menginsyafkan mereka tentang sebab-sebab sejarah dan tujuan Revolusi Kemerdekaan kita (Supardo dkk, 1962). Panitia tersebut berhasil menyusun buku "Manusia dan Masyarakat Baru Indonesia" pada tahun 1962. Menurut para penulisnya (Supardo, dkk.), buku ini dapat disebut dengan istilah Jerman "Staatsburgerkunde", dengan istilah Inggris "Civics" atau dengan istilah Indonesia "Kewarganegaraan". Akan tetapi oleh karena isi buku ini agak luas maka, nama "Manusia dan Masyarakat Baru Indonesia" agaknya lebih tepat.

Buku pedoman PKn tersebut berisi (1) Sejarah pergerakan/perjuangan rakyat Indonesia, (2) Pancasila, (3) UUD 1945, (4) Demokrasi dan Ekonomi Terpimpin, (5) Konferensi Asia Afrika, (6) Kewajiban dan hak warganegara, (7) Manifesto Politik, (8) Laksana Malaikat dan Lampiran-lampiran tentang Dekrit Presiden, Lahirnya Pancasila, Pidato Presiden Soekarno, Declaration of Human Rights dan Panca Wardhana (lima perkembangan). Pada dasarnya bahan pelajaran kewarganegaraan tersebut telah digunakan sejak 1959 sampai dengan pecahnya Pemberontakan Partai Komunis Indonesia (PKI) pada tanggal 30 september 1965. Selanjutnya, setelah terjadinya pemberontakan PKI, istilah Pendidikan Kewarganegaraan atas usul Menteri Kehakiman waktu itu, Mr. Suhardjo, diubah menjadi Pendidikan Kewargaan Negara dan berlaku sampai dengan tahun 1968. Dengan diberlakukannya Kurikulum 1968 namanya berubah lagi menjadi "Pendidikan Kewarganegaraan".

PKn menurut kurikulum 1968 berada dalam Kelompok Pembinaan Jiwa Pancasila baik di sekolah Dasar maupun di sekolah Menengah. Bedanya adalah di SD kelompok mata pelajaran terdiri dari Pendidikan Agama, Pendidikan Kewarganegaraan, Bahasa Indonesia, Bahasa Daerah, dan Olah Raga. Sedangkan di SMA tanpa Bahasa Daerah. Bahan-bahan pengajaran PKn menurut kurikulum 1968 tersebut digunakan sampai dengan ditetapkannya Pendidikan Kewarganegaraan dalam Kurikulum 1975 dengan nama "Pendidikan Moral Pancasila" (PMP) sebagai nama Bidang Studi (BS) untuk Pendidikan Kewarganegaraan yang tujuannya adalah untuk membentuk warganegara Pancasilais yang beriman dan bertaqwa kepada Tuhan Yang Maha Esa. Dengan ditetapkanya ketetapan MPR No. II/MPR/1978 tentang Pedoman Penghayatan dan Pengamalan 
Pancasila (P4) maka materi bidang studi PMP dilengkapi atau bahkan di dominasi oleh materi (P4) yang cenderung sebagai bahan indoktrinasi untuk pendidikan dan pelatihan warganegara.

Sebagaimana telah dikemukakan di atas PKn telah muncul dengan berbagai nama. Numan Somanteri (1972) mengemukakan bahwa istilah "Civics dan Civics Education" telah muncul masingmasing dengan nama: Pendidikan Kewarganegaraan (1957); Civics (1962); dan Pendidikan Kewargaan Negara (1968). Pendidikan Kewarganegaran (1957) membahas materi tentang cara memperoleh dan kehilangan kewarganegaraan. Sedang Civics (1962) lebih banyak membahas Sejarah Kebangkitan Nasional, UUD, Pidato-Pidato Politik Kenegaraan, terutama yang diarahkan untuk "nation and character building” bangsa Indonesia, seperti pada waktu pelaksanaan pelajaran Civics di Amerika Serikat pada tahun-tahun setelah Declaration of Independent. Pidato-Pidato Politik Kenegaraan ini dikemas dengan nama "Tujuh Bahan Pokok Indoktrinasi" (TUBAPI) yang berisi pidato-pidato politik kenegaraan mantan Presiden Soekarno ditambah dengan Manifesto Politik (Manipol) dan Undang-Undang Dasar 1945, Sosialisme Indonesia, Demokrasi dan Ekonomi Terpimpin, Kepribadian Indonesia (USDEK). Pada masa pemerintahan Orde Baru bahan-bahan pelajaran yang bersifat indoktrinasi tersebut dibuang dan dihilangkan sama sekali melalui Kurikulum 1968 dengan melakukan perubahan-perubahan materi dan metode penyampaian. Adapun materi pelajaran atau kelompok mata pelajaran untuk Pendidikan Kewarganegaraan tersebut adalah Kelompok Pembinaan Jiwa Pancasila. Kelompok Pembinaan Jiwa Pancasila ialah Kelompok segi pendidikan yang terutama ditujukan kepada pembentukan mental dan moral Pancasila serta pengembangan manusia yang sehat dan kuat fisiknya dalam rangka pembinaan bangsa.

Tujuan diajarkannya Pendidikan Kewargaan Negara adalah agar tiap-tiap warganegara Indonesia berkewajiban mengamalkan Pancasila dan UUD 1945 serta merealisasikan isi dan jiwa UUD 1945 dan ketetapan-ketetapan MPRS sebagai ketentuan-ketentuan pelaksanaannya. Dengan demikian Kewargaan Negara tidak saja wajib dipelajari tetapi lebih-lebih lagi merupakan bentuk sikap hidup. Salah satu hal penting dari kurikulum SMA 1968 tersebut adalah pengajaran Mata Pelajaran Kewargaan Negara senantiasa dikorelasikan dengan pelajaran lain seperti Sejarah Indonesia, Ilmu Bumi Indonesia, Hak Asasi Manusia, dan Ekonomi, sehingga mata pelajaran Kewargaan Negara menjadi lebih hidup, lebih menantang, dan lebih bermakna. 


\section{Pendidikan Kewarganegaraan Pada Era Orde Baru}

Dalam perubahan kurikulum sekolah tahun 1968 menjadi kurukulum tahun 1975 mata pelajaran PKn atas dasar Keputusan MPR 1978 diganti dengan nama baru yang dikenal dengan Pendidikan Moral Pancasila (PMP). Ini merupakan hasil penggabungan mata pelajaran sejenis menjadi bidang studi. Bidang studi PMP merupakan bahan-bahan mata pelajaran yang menyangkut Pancasila dan UUD 1945 dipisahkan dari mata pelajaran yang bersangkut paut di antaranya mata pelajaran Sejarah, Ilmu Bumi, dan Ekonomi. Sedangkan gabungan mata pelajaran Sejarah, Ilmu Bumi, dan Ekonomi menjadi bidang studi Ilmu Pengetahuan Sosial (IPS) atau Studi Sosial (Social Studies) dan saat ini bernama Pendidikan Ilmu Pengetahuian Sosial (PIPS). Hal yang sama masih tetap berlaku saat berlakunya Kurikulum 1984 sebagai penyesuaian Kurikulum 1975. Mengenai bidang studi PMP tersebut Depdikbud (waktu itu) telah mengeluarkan Penjelasan Ringkas tentang Pendidikan Moral Pancasila (Dikbud, 1982) di mana dikemukakan berbagai hal penting antara lain adalah sebagai berikut:

Pendidikan Moral Pancasila (PMP) secara konstitusional mulai dikenal dengan adanya TAP MPR No. IV/MPR/1973 tentang Garis-garis Besar Haluan Negara. Dengan adanya Ketetapan MPR No. II/MPR/1978 tentang Pedoman Penghayatan dan Pengamalan Pancasila (P4), maka materi PMP didasarkan pada isi P4 tersebut. Oleh karena TAP MPR No. II/MPR/1978 merupakan penuntun dan pegangan hidup bagi sikap dan tingkah laku setiap manusia Indonesia dalam kehidupan bermasyarakat serta bernegara, maka dijadikan sumber, dan tempat berpijak, isi, dan evaluasi PMP. Dengan demikian hakikat PMP tiada lain adalah pelaksanaan P4 melalui jalur pendidikan formal. Di samping pelaksanaan PMP di sekolah-sekolah di dalam masyarakat umum giat diadakan usaha pemasyarakatan P4 lewat berbagai penataran, dalam rangka menyesuaikan Kurikulum 1975 dengan P4 dan GBHN 1978 mengusahakan adanya buku pegangan bagi murid dan guru Sekolah Dasar, Sekolah Menengah Tingkat Pertama dan Sekolah Menengah Tingkat Atas. Usaha itu telah menghasilkan Buku Paket PMP.

Dari penjelasan ringkas di atas dapat disimpulkan bahwa: (1) P4 merupakan sumber, dan tempat berpijak, isi, dan cara evaluasi PMP melalui pembakuan kurikulum 1975; (2) dengan dihasilkannya Buku Paket PMP untuk semua tingkat pendidikan di sekolah maka Buku 
Pedoman Pendidikan Kewarganegaraan, Manusia dan Masyarakat Baru Indonesia, dinyatakan tidak berlaku lagi; dan (3) P4 tidak hanya diberlakukan untuk sekolah-sekolah tetapi juga untuk masyarakat pada umumnya melalui berbagai penataran Pedoman Penghayatan dan Pengamalan Pancasila (P4) oleh BP7, untuk sekolah diberlakukan bidang studi PMP sedangkan untuk masyarakat diberlakukan P4. Namun demikian materi PMP tersebut didominasi oleh bahan-bahan P4 yang disesuaikan dengan masing-masing lingkungan, yaitu lingkungan sekolah dan lingkungan masyarakat.

Dalam perkembangan selanjutnya PMP karena berbagai perubahan dan berbagai pertimbangan, dengan disusunnya kurikulum sekolah tahun 1994 diubah menjadi Pendidikan Pancasila dan Kewarganegaraan (PPKn) yang terutama didasarkan pada UU Sistem Pendidikan Nasional No. 2 tahun 1989 ayat 2 yang menyatakan bahwa: "Isi kurukulum setiap jenis, jalur, dan jenjang pendidikan wajib memuat: a. Pendidikan Pancasila; b. Pendidikan Agama; dan c. Pendidikan Kewarganegaraan.

\section{Pendidikan Kewarganegaraan Pada Era Reformasi}

Demokratisasi bidang pendidikan amat diperlukan terutama dalam memposisikan warganegara sebagai subjek dan bukan sekedar objek dari kepentingan politik penguasa semata. Demokratisasi di bidang pendidikan yang ditindaklanjuti dengan pendidikan demokrasi adalah suatu yang memungkinkan upaya pengembangan segenap potensi individu warganegara Indonesia secara optimal sesuai dengan fitrah insaninya (Senat IKIP Bandung, 1999). Guna memperoleh perbandingan, memperluas visi dan memberi dasar yang kokoh bagi pendidikan untuk warganegara demokratik "democratic citizenship" yang seharusnya menjadi dasar pendidikan Indonesia dalam era reformasi tersebut ada baiknya mengutip pendapat Thomas Jefferson sebagai penulis Deklarasi Kemerdekaan Amerika yang menyatakan bahwa: "...that the knowledge, skills and behaviors of democratic citizenship do not just occur natullay in oneself but rather they must be taught consciously through schooling to teach new generation, i.e they are learned behaviors". Agar peran pendidikan dipahami secara jelas dalam mendidik warganegara yang demokratis tersebut John F. Kennedy misalnya lebih memperkuat pendapat Jefferson dengan mengatakan bahwa: "There is an old saying that the course of civilization is a race between catastrophe and education. In a 
democracy such as ours, we must make sure that education wins the race”.

Kedua pandangan tersebut memberi isyarat yang jelas bahwa pendidikan amat berperan dalam mendidik warganegara yang demokratis, yang menyiratkan dan mensyaratkan bahwa pendidikan itu sendiri haruslah demokratis dan dilakukan dengan cara-cara yang demokratis pula sebab pendidikan harus efektif yang didukung oleh faktor-faktor startegis lingkungan internal dan eksternal. Dalam konteks itu dapat diidentifikasikan parameter dan variabel yang signifikan, baik yang berhubungan dengan proses belajar mengajar, evaluasi, sistem kurikulum, sistem manajemen dan faktor kontekstual sosial, ekonomi, politik, hukum dll, yang dibangun oleh sumber daya manusia yang kompeten dan teruji. Jika pendidikan itu mau efektif, ia harus kuat, punya kemandirian, dan hubungan saling bantu dengan faktor eksternalnya dengan anggaran yang cukup untuk membiayai SDM. Pendidikan Kewarganegaraan yang efektif selain yang tersebut di atas, perlu visi yang dibangun bersama tentang warganegara yang baik, demokratis, cerdas, dan terampil dalam menuju masyarakat madani.

Keadaan masa lalu menunjukkan betapa rapuhnya pembangunan termasuk pembinaan warganegara yang hanya mengandalkan faktor keamanan, ekonomi, atau teknologi belaka tanpa memikirkan secara sungguh sungguh individu-individu warganegara sebagai SDM yang akan terlibat dalam keseluruhan sistem yang dibentuk dengan berbagai pendekatan tersebut. Pendekatan-pendekatan yang dianut dalam pembangunan bangsa dan warganegara masa lalu itu secara nyata telah menunjukkan kegagalan-kegagalannya. Keadaan seperti ini mendorong kita semua untuk memikirkan penataan kembali pendidikan bagi warganegara Indonesia khususnya PKn Indonesia. Dengan mencermati ciri-ciri PKn dalam kedua kurun waktu di atas nampak bahwa baik substansi materi maupun metode mengajarnya tidak terlalu banyak mengalami perubahan, bahkan dapat dikatakan bahwa kelemahannya justru terletak pada ketidak-konsistenan dalam melaksanakan apa yang ditetapkan oleh kurikulum.

\section{Analisis}

Telah diuraikan terdahulu bahwa ketiga rezim pemerintahan memiliki perhatian yang begitu signifikan terhadap PKn. Hal itu dapat dilihat dari berbagi kebijakan pendidikan khususnya tentang Pendidikan Kewarganegaraan yang seolah-olah amat dipengaruhi oleh 
perubahan-perubahan situasi politik dan kenegaraan. Pada masa-masa yang lalu yang jika tujuannya dicermati senantiasa menempatkan PKn tersebut sebagai "alat politik" bukan sebagai "alat pendidikan politik" yang didasari oleh nilai-nilai demokrasi tetapi justru untuk mengarahkan dan mendominasi nilai-nilai yang memungkinkan sebuah rezim untuk mempertahankan "kemapanan" yang mendukung kekuasaan yang ada.

Perubahan-perubahan tersebut terjadi karena adanya perubahan dalam sistem sosial politik, dan kenegaraan yang memang semakin menuntut pada kemantapan dalam PKn untuk menjamin kelangsungan hidup Negara Kesatuan Republik Indonesia (NKRI). Adanya tuntutantuntutan perubahan ke arah kehidupan yang lebih demokratis harus diakui sebagai hasil positif dari pendidikan PKn belakangan ini termasuk ekses yang sekaligus merupakan tantangan bagi proses demokratisasi itu sendiri.

Tuntutan perubahan itu selain disebabkan oleh hal-hal seperti disebutkan di atas, dan juga karena beberapa sebab lain yang amat fundamental seperti dikemukakan oleh Aziz Wahab (1998) dengan mengatakan bahwa: Bidang Studi PKn sesuai fungsi dan tujuannya selama ini menjadi sarana untuk membina warganegara untuk lebih mengetahui hak dan kewajibannya dalam kehidupan berbangsa dan bernegara. Namun sejalan dengan terjadinya reformasi diperlukan kajian ulang terhadap relevansi meteri PKn dalam kurikulum karena beberapa alasan, di antaranya: (1) Selama Orde Baru yang lalu ada kekacauan pengertian antara negara dan pemerintah/rezim yang berkuasa; seakan-akan keduanya menjadi identik. Hal itu mengakibatkan penerjemahan PKn ke dalam kurikulum pun banyak diwarnai oleh perspektif dan kepentingan pemerintah dengan mengatasnamakan perspektif dan kepentingan negara. Hal yang sama sesungguhnya bukan hanya berlaku untuk PKn tetapi juga untuk bidang-bidang studi lainnya seperti Sejarah, Ekonomi, dan Geografi. (2) Karena alasan pertama di atas, topik-topik tertentu lebih banyak diangkat (misalnya soal kepatuhan, kesetiaan pada pemerintah yang berkuasa, keamanan nasional) yang bertujuan menguatkan kedudukan pemerintah yang berkuasa; sedangkan topik-topik lain seperti hak asasi manusia, demokrasi politik, demokrasi ekonomi, hak-hak rakyat, kewajiban pemerintah kepada publik, kebebasan menyatakan pendapat, kebebasan beragama, kurang ditampilkan secara proporsional. (3) $\mathrm{PKn}$ adalah sarana pendidikan politik bangsa. Namun pendidikan politik yang dimaksud selama ini cenderung "sepihak" dan "monolog", yaitu mendukung kelanggengan 
kekuasaan orde yang berkuasa. Akibatnya siswa tidak disiapkan untuk berpikir secara dewasa, bertanggung jawab dan jujur bahkan terhadap dirinya sendiri. Produk akhirnya adalah peserta didik yang "tanpa pilihan", harus menerima apa adanya tanpa dapat dan mampu mempertanyakan hal-hal di luar koridor yang telah ditentukan sebelumnya. Dari sudut perkembangan moral, hal ini tidak menguntungkan karena membuat siswa menjadi kerdil dalam berpikir. PKn lebih menekankan segi "to tell students about what are desiable behaviors" dan bukan "to ask and let student to think and to find...". (4) Dalam kenyataan, terjadi berbagai kebingungan peserta didik akibat apa yang diajarkan di sekolah berbeda kenyataannya. Akibat lanjutnya adalah secara tidak disadari kita menyiapkan generasi yang memiliki kepribadian terpecah.

Berdasarkan alasan-alasan di atas, kaji ulang dan peninjauan kembali terhadap materi dan metodologi PKn dalam kurikulum 1994 merupakan suatu keharusan dalam Era Reformasi sekarang ini. Kaji ulang diarahkan terhadap hal-hal berikut ini:

1. Sejauh manakah materi yang ada dalam kurikulum masih relevan dengan semangat bangsa kita yang dengan memanfaatkan momentum reformasi sedang memformulasikan kembali format dan implementasi nilai-nilai Pancasila dalam kehidupan berbangsa dan bernegara.

2. Banyak keluhan selama ini tentang padat dan banyaknya materi yang mesti dipelajari oleh siswa. Hal ini pun perlu dikaji ulang, materi manakah yang dapat dikeluarkan, digabungkan, dirampingkan, dan materi mana yang benar-benar esensial bagi anak, masyarakat, dan kehidupan bangsa.

3. Dari segi metodologi, metode yang cenderung doktriner dan monolog selama ini, perlu ditinjau ulang dari segi karakter belajar dan tahap-tahap perkembangan peserta didik. Sudah cukup lama kita mengetahui bahwa PKn adalah pelajaran yang "membosankan" bahkan cenderung "tidak disukai" siswa karena materi dan metodenya memang tidak menantang siswa secara intelektual, di samping amat sarat dengan pesan-pesan ideologis rezim yang berkuasa.

Dalam era reformasi dan dalam kehidupan demokrasi setiap orang sebagai warganegara memperoleh kebebasan dan diperlakukan secara adil. Untuk itu setiap warganegara harus memperoleh kesempatan yang sama untuk memperoleh pendidikan yang baik. Dalam pendewasaan dan sikap keterbukaan dan kebebasan itu baik politik maupun ekonomi itu harus dijelaskan secara tuntas bahwa: 
dasar-dasar demokrasi itu sebagaimana dikemukakan oleh Chapin dan Messick (1989: 114) di antaranya adalah seperti berikut: "Each person has one vote; Citizens have equal protection under the law; Decuisions and laws can be reviewed and amended by lawful process; Decisions and government acts are based on law”.

Tujuannya adalah agar setiap warganegara menjadi cerdas, dapat berpikir kritis dan kreatif serta memiliki sikap disiplin pribadi dan dapat berpartisipasi dalam mengatasi berbagai persoalan baik pribadi, maupun masyarakat lingkungannya. Lahirnya warganegara seperti itu menuntut perubahan-perubahan mendasar dalam pendidikan pada umumnya dan pendidikan kewarganegaraan khususnya.

\section{Penutup}

Uraian di atas telah membawa kita, bangsa Indonesia, untuk tidak mengulangi langkah-langkah politik yang keliru yang cenderung lebih menekankan kepada kekuasaan dengan menomorduakan rakyat dan masyarakat dalam sistem kehidupan berbangsa dan bernegara. Pengakuan terhadap hak-hak individu yang didasari rasa tanggung jawab harus ditambahkan. Penghargaan dan penghormatan terhadap hak-hak dasar manusia serta lebih menekan lagi pada kemajuan dan kesejahteraan rakyat harus sudah mulai menjadi dasar-dasar kebijakan nasional dengan senantiasa membuka diri terhadap perubahan global dan dengan respon yang dilakukan secara cerdas.

Semua itu hanya mungkin dapat dicapai jika dilakukan perubahan paradigma terhadap $\mathrm{PKn}$. Paradigma baru tersebut menuntut diakukannya redifinisi dan revitalisasi implementasi konsep PKn sehingga benar-benar menjadi sebuah wadah yang dapat membangun dan mengembangkan berbagai kemampuan warganegara agar dapat lebih sensitif, proaktif, inovatif, dan kreatif, serta cerdas sehingga dapat berpartisipasi secara aktif dan efektif dalam kehidupannya sebagai warganegara dan warga masyarakat.

Redifinisi dan revitalisasi pengertian serta tujuan PKn akan mendorong lahirnya paradigma baru PKn. Paradigma baru tersebut harus disusun di atas pilar-pilar demokrasi yang akan mendukung nuansa demokratis yang saat ini telah berkembang di masyarakat. Paradigma baru PKn tersebut menuntut adanya perubahan dalam seluruh aspek pembelajaran PKn dimulai dari tujuan sampai pada pengembangan bahan ajar, metode mengajar, dan penilaiannya. 


\section{Daftar Pustaka}

Abdul Azis Wahab. (1998). Kajian Terhadap Kinerja Kurikulum 1994 dan Faktor-Faktor yang Mempengaruhi. Bandung: Jurusan PPKN IKIP Bandung.

Azyumardi Azra. (2006). Paradigma Baru Pendidikan Nasional. Jakarta: Penerbit Buku Kompas.

Depdikbud. (1968). Kurikulum Pendidikan Dasar dan Menengah. GBPP PKn.

Depdikbud. (1993). Kurikulum Pendidikan Dasar dan Menengah. GBPP PKn.

Depdikbud. (1982). Penjelasan Ringkas Tentang Buku PMP. Ditjen. Dasmen.

Muchson AR. (2004). "Pendidikan Kewarganegaraan Paradigma Baru”. Jurnal Civics. Vol. 1, No. 1 Juni 2004.

Numan Somantri. (1972). "Beberapa Masalah dalam Pengajaran PKn”. Seminar Nasional Civic, Surakarta: Tawangmangu.

Print, Murray et al. (1999). Civic Education for Civil Society. London: Asian Academic Press.

Redaksi Sketsa Masa. (1961). Tujuh Bahan Pokok Indoktrinasi. Surabaya: Penerbit GRIP.

Suryadi, Ace dan Somantri. (2000). "Pemikiran Ke Arah Rakayasa Kurikulum Pendidikan Kewarganegaraan". Paper dalam The International Seminar: The Need for New Indonesian Civic Education, March 29, 2000, at Bandung.

Supardo dkk. (1962). Manusia dan Masyarakat Baru Indonesia. Jakarta: Balai Pustaka.

Waterwoth, Peter. (1998). "Trends in Social Studies Education and Citizenship Education". Paper. Faculty of Education, Deakin University, Australia.

Sunarso, M.Si., lahir di Karanganyar, 21 Mei 1960. Lulus S-1 Fisipol UGM Yogyakarta tahun 1985. Lulus S-2 Ketahanan Nasional PPS UGM Yogyakarta 1995. Sejak tahun 1987 menjadi tenaga pengajar di Fakultas Ilmu Sosial Universitas Negeri Yogyakarta. 